\title{
Ronald Dworkin and the Curious Case of the Floodgates Argument
}

\author{
Noam Gur
}

\begin{abstract}
This article juxtaposes a jurisprudential thesis and a practical problem in an attempt to gain critical insight into both. The jurisprudential thesis is Dworkin's rights thesis. The practical problem revolves around judicial resort to the floodgates argument in civil adjudication (or, more specifically, a version of this argument focused on adjudicative resources, which is dubbed here the FA). The analysis yields three principal observations: (1) Judicial resort to the FA is discordant with the rights thesis. (2) The rights thesis is instructive in one way but mistaken in another. While Dworkin has highlighted some valid and sound reasons against judicial policymaking, his conclusive exclusion of judicial policymaking from civil law adjudication is erroneous. Civil law adjudication, it is argued, is an arena of ineliminable tension between principle and policy. (3) The FA is a type of policy argument particularly vulnerable to objections against judicial policymaking. There should, therefore, be a (rebuttable) presumption against judicial resort to it.
\end{abstract}

A well-known thesis of Ronald Dworkin contends that judicial decisions in civil cases, even in hard cases, characteristically are-and should be-generated by principle not policy. ${ }^{1}$ This thesis, sometimes referred to as "the rights thesis", ${ }^{2}$ undoubtedly picks out an

Early drafts of this paper were presented in workshops at the Centre for Law and Society in a Global Context, Queen Mary University of London; the Legal Theory Research Group, University of Edinburgh; and the World Congress of IVR, Washington DC, 2015. I thank the participants and audiences in these fora-and particularly Maks Del Mar, Luís Duarte d'Almeida, Kenneth Ehrenberg, Steve Hedley, Briain Jansen, Tsachi Keren-Paz, Dimitrios Kyritsis, Dorota Leczykiewicz, Haris Psarras, Nick Sage, Lawrence Sager, Fábio Shecaira, and Richard Waltersfor helpful comments and questions. I am also grateful for beneficial comments by an anonymous CJLJ referee. Finally, I would like to thank Juliette Guiot for her valuable work as a research assistant.

\footnotetext{
${ }^{1}$ Ronald Dworkin, Taking Rights Seriously (Duckworth, 1977) at 84. See also Ronald Dworkin, Law's Empire (Harvard University Press, 1986) at 244. Two clarifications: (1) The qualifier "characteristically" in the above formulation of the thesis refers to how cases are decided, not to how they should be decided. At the prescriptive level, Dworkin maintains that, at least in common law decisions, judges should never decide on the basis of policy. His position on how they should interpret statutes will be specified later (body text accompanying notes 27-33). (2) The thesis, as stated above, refers to civil cases. In criminal cases, in contrast, Dworkin seems to suggest an asymmetrical exclusion of policy arguments, namely, such that defendants have a right that policy arguments be barred from serving as a ground for conviction, but the prosecution has no right that policy considerations for acquittal be disregarded (Dworkin, Taking Rights Seriously, ibid). For brevity, I will sometimes leave out the scope qualifier "civil" and use broad terms such as "adjudication" or "judicial reasoning". But the intended scope of my analysis remains civil law.

${ }^{2}$ Dworkin, Taking Rights Seriously, supra note 1 at 87-90.
} 
issue of key significance for legal scholars and practitioners alike: the relationship between principle and policy in adjudication. However, its descriptive and prescriptive contentions may prompt (and have not infrequently prompted) sceptical reactions. "Do judges in civil law cases"- it may be queried at the descriptive level_ " not characteristically consider policy arguments and make policy decisions?" And a notable example Dworkin's critic may use to press the point is the so-called floodgates argument. Judicial resort to the floodgates argument, the critic may say, is a clear example of a policy argument operating in adjudication. This likely challenge has not eluded Dworkin's attention. Indeed, we find in one of his most renowned texts, the essay "Hard Cases", 3 a discussion of judicial recourse to the floodgates argument (or at least one version of the floodgates argument). Dworkin insists there, however, that judicial recourse to this argument is reconcilable with his rights thesis.

I would like to address two principal questions concerning the rights thesis, the floodgates argument, ${ }^{4}$ and the relationship between them. First, was Dworkin right to argue that judicial resort to the floodgates argument is compatible with the rights thesis? And, second, if the two are incompatible, which of them should be accepted and which should be rejected? Should we accept the rights thesis and thus conclude that judges should not avail themselves of this argument, or vice versa? As may be seen from these questions, the aim and relevance of this inquiry are dual. At its highest level of generality, it seeks to assess a jurisprudential claim about how judges do and should decide cases (i.e. the rights thesis). At a more specific level, it sets out to consider the proper role, if any, of a particular type of argument in adjudication (i.e. that the court should avoid a decision that would lead to an excessive upsurge in the volume of litigation).

A few clarifications are needed at this preliminary point. First, the reader will have noticed that most, if not all, of the cases mentioned in this paper are tort cases. That is not merely because tort law is the civil law area I am most closely familiar with, but also because many of the cases where the floodgates argument has been invoked are tort cases. But I see no reason to think that the conclusions arrived at here do not apply to civil law areas other than tort law. ${ }^{5}$ Second, it should be noted that Dworkin makes no express use of

\footnotetext{
${ }^{3}$ Ibid at $81,100$.

${ }^{4}$ Or, more precisely, the version of floodgates argument discussed by Dworkin.

${ }^{5}$ And to jurisdictions other than those featuring in my examples.
} 
the phrase "the floodgates argument" in the relevant text. But the argument he discusseswhich he refers to as "the familiar argument that certain sorts of law suits should not be allowed because to do so would 'swamp' the courts with litigation" same argument known as the floodgates argument or at least one version thereof. ${ }^{7}$ This takes us to a third clarification, which distinguishes the version discussed by Dworkin from other versions of the floodgates argument. The argument discussed by Dworkin focuses on the court system's capacity to adjudicate the volume of future lawsuits anticipated if a given lawsuit is accepted. This is one argument that features in the case law and literature under the label "the floodgates argument", ${ }^{8}$ but it is not the only one. There are other arguments that, although frequently couched in other terms such as "crushing liability" or more generally "policy arguments", at times appear under, or in connection with, the label "the floodgates argument". In these other arguments, ${ }^{9}$ the anticipated surge of legal claims

\footnotetext{
${ }^{6}$ Dworkin, Taking Rights Seriously, supra note 1 at 100. Elsewhere Dworkin adverts to a concern about "the 'flood' of litigation" and "[c]ongestion in the courts" (Dworkin, Law's Empire, supra note 1 at 28$)$.

${ }^{7}$ This is clear both from Dworkin's above-quoted description of the argument and from his subsequent comments.

${ }^{8}$ See, e.g., Kirsty Horsey and Erika Rackley, Tort Law, 2nd ed (Oxford University Press, 2011) at 57-58 (referring to "a wish to prevent a 'flood' of claims ... which may in turn clog-up or slow down the tort system as a mechanism for compensation"); John Cooke, Law of Tort, 10th ed (Pearson, 2011) at 6-7 (noting that "[t]he courts are concerned with opening the floodgates of litigation", and referring to "the fear of the courts being swamped by a large number of actions"); Michael A Jones, Textbook on Torts, 8th ed (Oxford University Press, 2002) at 96 ("The courts have been traditionally wary of actions which might lead to a flood of claims inundating them with work (the 'floodgates' argument)"). For relevant judicial comments, with or without express reference to the label "the floodgates argument", see, e.g., Spartan Steel \& Alloys Ltd v Martin \& Co. (Contractors) Ltd [1973] QB 27 (hereafter: Spartan Steel) at 38 (Lord Denning noting, albeit in passing, that the cutting of electricity supply "affects a multitude of persons"); White $v$ Chief Constable of South Yorkshire Police [1999] 1 All ER 1 (hereafter: White) at 6 (Lord Griffiths referring to the argument that "if foreseeability of psychiatric injury is sufficient it will open the floodgates to claims, many of an unmeritorious kind, from those who give assistance at any accident", but rejecting it as he notes that "the courts are well capable of controlling any such flood of claims"); Rothwell v Chemical \& Insulating Co. Ltd [2007] 4 All ER 1047 at 1066 (Lord Hope referring to the risk of giving rise to "litigation the costs of which were out of all proportion to what was in issue"). See also Esanda Finance Corporation v Peat Marwick Hungerfords [1997] HCA 8 (where the court considers the effect of auditors' liability "on the administration of the court system").

${ }^{9}$ Each version of the floodgates argument mentioned in the body text may, in fact, appear in at least three forms: (i) where it is anticipated that the flood of lawsuits would be in cases of the same type as the one at hand; or (ii) where it is feared that recognizing liability in the present type of case would carry with it further expansions of liability in other types of case due to what William Prosser
} 
is treated as a problem, not because the sheer number of claims would place excessive demands on the court system, but for other reasons: for example, the large or indeterminate amount of liability defendants of the relevant type would be exposed to ${ }^{10}$ (and/or consequent inhibiting effects on socially beneficial activities performed by those defendants ${ }^{11}$ ); evidentiary difficulties connected with the relevant kind of lawsuits; ${ }^{12}$ or a wish to discourage litigious attitudes in society as an undesirable phenomenon in and of itself. ${ }^{13}$ Apart from some incidental comments on these arguments, my focus will be on the version of the floodgates argument discussed by Dworkin (which, for ease of reference, I

termed "the problem of finding a place to stop and draw the line" (Handbook on the Law of Torts, 4th ed (West, 1971) at 256); or (iii) where both (i) and (ii) are involved.

${ }^{10}$ Junior Books Ltd v Veitchi Co. Ltd [1983] 1 AC 520 at 532 (Lord Fraser citing in connection with the floodgates argument Cardozo CJ's famous warning against introducing "liability in an indeterminate amount for an indeterminate time to an indeterminate class" in Ultramares Corporation v Touche (1931) $174 \mathrm{NE} \mathrm{441,} \mathrm{at} \mathrm{444);} \mathrm{Leigh} \mathrm{\&} \mathrm{Sillavan} \mathrm{Ltd} \mathrm{v} \mathrm{Aliakmon} \mathrm{Shipping} \mathrm{Co.}$ Ltd (The Aliakmon) [1986] AC 785 at 816 (Lord Brandon referring to a policy concern "to avoid the opening of the floodgates so as to expose a person guilty of want of care to unlimited liability to an indefinite number of other persons whose contractual rights have been adversely affected by such want of care"); White, supra note 8 at 33 (Lord Steyn referring to "a burden of liability on defendants which may be disproportionate to tortious conduct involving perhaps momentary lapses of concentration, e.g. in a motor car accident"; the phrase "flood of litigation" appears shortly after, at 34); Cooper v Hobart [2001] SCC 79 at para 54 (where it is noted that "the spectre of indeterminate liability would loom large if a duty of care was recognized ...").

${ }^{11}$ M v Newham London Borough Council [1994] 4 All ER 602 at 630 (Staughton LJ referring to the argument that "a new development will open the floodgates to litigation", and noting that if a duty of local authorities be recognized in the case at hand "many claims will be brought, placing further strain in an already stretched system [i.e. social welfare system]").

${ }^{12}$ Spartan Steel, supra note 8 at 38 (Lord Denning noting: "[I]f claims for economic loss were permitted for this particular hazard, there would be no end of claims. Some might be genuine, but many might be inflated, or even false. A machine might not have been in use anyway, but it would be easy to put it down to the cut in supply. It would be well-nigh impossible to check the claims"); White, supra note 8 at 32-33 (Lord Steyn referring to "the complexity of drawing the line between acute grief and psychiatric harm" and noting that "there is greater diagnostic uncertainty in psychiatric injury cases than in physical injury cases"; the phrase "flood of litigation" is cited at 34).

${ }^{13}$ Spartan Steel, supra note 8 at 38 (Lord Denning: "[M]ost people are content to take the risk on themselves. When the [electricity] supply is cut off, they do not go running round to their solicitor. ... They try to make up the economic loss by doing more work next day. This is a healthy attitude which the law should encourage"); White, supra note 8 at 33 (Lord Steyn: "The litigation is sometimes an unconscious disincentive to rehabilitation [in the context of psychiatric harm]"); John Munroe (Acrylics) Ltd v London Fire and Civil Defence Authority [1996] 4 All ER 318 at 332 (Rougier J: "[B]y far the most important consideration, is what is sometimes referred to as the 'floodgates' argument"; and a few lines below: "There seems to be a growing belief that every misfortune must, in pecuniary terms at any rate, be laid at someone else's door, and after every mishap, every tragedy, the cupped palms are outstretched for the solace of monetary compensation. Claims which would have been unheard of 30 years ago are now being seriously entertained ..."). 
will henceforth call "the FA"). An inquiry focused on the other arguments just mentioned is a task left for another occasion.

A fourth and final clarification concerns the scope of my jurisprudential inquiry. It is an examination of one specific thesis of Dworkin (albeit one assigned by Dworkin an important place in his theory of law): the rights thesis. It is not a general appraisal of his theory of law. Thus, for example, it does not discuss Dworkin's position on the truth conditions of propositions of law, and his debate with legal positivists over this matter (or, to frame this in more typically positivist terms, their debate over the criteria of legal validity). While the latter topic is not entirely unrelated to the rights thesis's subject matter, the two are distinct; and, as far as I can see, none of the arguments I put forward here entails this or that answer to the question of the truth conditions of legal propositions (or the criteria of legal validity).

\section{A BRIEF EXPOSITION OF DWORKIN'S RIGHTS THESIS}

I turn to a brief description of Dworkin's claims relevant to this inquiry. Dworkin's rights thesis is, in large measure, a reflection of the way he sees the contrast between courts on the one hand and legislative bodies on the other. The operation of legislative bodies, he readily accepts, characteristically involves policymaking. ${ }^{14}$ This is a normal and legitimate part of their institutional role and responsibility. That is not the case, however, with decisions made by courts; decisions of this type, according to him, characteristically are and should be decisions of principle, not policy. It should be added straight away, however, that the general idea of courts as a forum of principle takes, according to Dworkin, somewhat different shapes depending on whether the relevant judicial decision is common law or statute-based. This variation will be specified below. Before that, however, the exact meaning of "policy" and "principle" in Dworkin's theory will be spelled out.

Arguments of policy are described by Dworkin as arguments that justify a political decision by showing that the decision promotes or safeguards "some collective goal of the community as a whole". ${ }^{15}$ Thus, for example, an argument calling for the introduction of a public subsidy for aircraft manufacturers on the grounds that it would contribute to national

\footnotetext{
${ }^{14}$ Dworkin, Taking Rights Seriously, supra note 1 at 83.

${ }^{15}$ Ibid at 82 .
} 
defence, or an argument calling for an increase in government spending on infrastructure on the grounds that it would stimulate the economy, are both arguments of policy. ${ }^{16}$ Arguments of principle, on the other hand, are described by Dworkin as arguments that justify a decision by showing that it "respects or secures some individual or group rights" 17 (hence the label "the rights thesis"18). At the heart of any argument of principle, then, lies the supposition that the party on whose behalf the argument is made has a right to the outcome advocated by the argument - that it is entitled to it. It should be clarified that "rights" in the sense referred to here encompass not only the kind of human rights typically enshrined in a constitution, ${ }^{19}$ but any individual entitlement the law can be deemed to have conferred on the party in question.

It is also worth clarifying that, according to Dworkin, although arguments of principle are distinct from arguments of policy, they may arise from an earlier policy decision. Consider, for example, a statute instituting a scheme whereby all development projects of renewable energy are entitled to subsidies. The decision to enact the statute was based on environmentalist policy, but if, after the enactment, a renewable energy developer (call her Claire) claims a subsidy provided by the statute, she can do so, and most probably will, by recourse to an argument of principle. Thus, Claire's argument will not be that granting her a subsidy would help protect the environment (although this is likely to be consistent with her views), but rather that she is entitled to a subsidy pursuant to the statute. In Dworkin's words (referring to an analogous example), her "right to a subsidy no longer depends on any argument of policy because the statute made it a matter of principle". ${ }^{20}$

Another factor that helps explain the difference between policy and principle, according to Dworkin, is their relation to past decisions. When it comes to decisions based exclusively or predominantly on policy, the requirement for consistency with past decisions

\footnotetext{
${ }^{16}$ Ibid.

${ }^{17}$ Ibid.

${ }^{18}$ Ibid at $87-90$.

${ }^{19}$ Though rights of this kind may, of course, feature in an argument of principle-for example an argument of principle which advocates anti-discrimination legislation through an appeal to the right to equality (see, e.g., ibid at 82).

${ }^{20}$ Ibid at 83 .
} 
is relatively weak. ${ }^{21}$ The primary question policymakers ought to ask themselves is what type of scheme would best serve the goals and welfare of society, not what type of scheme is most consistent with past decisions. ${ }^{22}$ In decisions based on principle, on the other hand, there is an integral and relatively strong requirement of consistency with past decisions. A judge, for instance, characteristically does not (and should not) approach the resolution of a case as if it were simply an answer to the question: what decision would best serve society as a whole? The primary question he or she is meant to be answering, instead, is which of the parties before the court has a legal right to win the case. And one of the principal grounds for determining the parties' legal rights is what Dworkin calls the relevant institutional history-primarily, past legislative and judicial decisions-and the requirement that like cases be treated alike. ${ }^{23}$

It is not suggested here that the sense in which Dworkin uses the term "principle" is the only sense found in common, legal, or theoretical discourse. ${ }^{24}$ Quite possibly there exist other senses in some or all types of parlance - senses in which a decision might be said to be "principled" without implying that it is grounded in individual or group rights, and without excluding "policy" from its direct underpinnings. Indeed, the idea that a decision should best promote or safeguard "some collective goal of the community as a whole",25 might itself be described as a type of principle in some broad sense of the word. ${ }^{26}$ The sense of "principle" I am focusing on, however, is the particular sense defined by Dworkin in his above-cited statement. That is not because I think it represents an understanding of "principle" generally superior to others, but because this sense of "principle", as contrasted

${ }^{21}$ Ibid at 88, 113. See contra: Kent Greenawalt, "Policy, Rights, and Judicial Decision" (1976) 11 Ga L Rev 991 at 1001, 1008-10; Joseph Raz, "Professor Dworkin's Theory of Rights" (1978) 26:1 Political Studies 123 at 135. Cf Donald H Regan, "Glosses on Dworkin: Rights, Principles, and Policies" in Marshall Cohen, ed, Ronald Dworkin and Contemporary Jurisprudence (Duckworth, 1984) 119 at 132-40.

${ }^{22}$ Which is not to deny that the latter question may have some (indirect and limited) relevance for the former-for example, when it is considered that too frequent changes in political and social arrangements would introduce an unwelcome degree of instability into people's lives.

${ }^{23}$ Dworkin, Taking Rights Seriously, supra note 1 at 113.

${ }^{24}$ See, e.g., somewhat different senses of "principle" and "policy" referred to in Christian Witting, "Tort Law, Policy and the High Court of Australia" (2007) 31:2 Melb U L Rev 569, at 571-73.

${ }^{25}$ Which, to reiterate, Dworkin considers to be a defining characteristic of policy justifications (Dworkin, Taking Rights Seriously, supra note 1 at 82).

${ }^{26}$ See, e.g., George C Christie, "The Uneasy Place of Principle in Tort Law" (1996) 49 SMU L Rev 525 at 526 (referring to "the assumption that the law is seeking to achieve the more efficient allocation of society's resources" as a principle). See also at 541. 
with "policy", highlights what I consider to be a genuine and important tension in adjudication that other, broader senses of principle may obscure.

As mentioned earlier, Dworkin's conception of courts as a forum of principle takes somewhat different shapes depending on whether the relevant judicial decision is common law or statute-based. ${ }^{27}$ When it comes to common-law decisions, according to Dworkin, policy arguments should be entirely precluded from the court's reasoning process: "[j]udges must make their common-law decisions on grounds of principle, not policy", he states. ${ }^{28}$ Judicial interpretation of statutes, on the other hand, may legitimately take into account policy considerations relevant to the background justification of the statute in question. ${ }^{29}$ As Dworkin puts it at one point, the judge should fix to the relevant statutory language "arguments of principle or policy [emphasis added] that provide the best justification of that language in the light of the legislature's responsibility". ${ }^{30}$ Dworkin believes, however, that even when a judge makes this type of appeal to policy, the judge's reasoning ultimately "remains an argument of principle", for "he uses policy to determine what rights the legislature has already created". ${ }^{31}$ I am not certain, however, how to coherently understand Dworkin's position on this matter. "Policy" and "principle", as he seems to understand them, are mutually exclusive categories. How, then, can a statutory interpretation which, by Dworkin's own admission, is sensitive to, and influenced by, policy considerations end up being classified by Dworkin in the category of "principle" just because the judge, as he puts it, "uses policy to determine what rights the legislature has already created"? But even if Dworkin coherently accommodates policy in his conception of statutory interpretation, this cannot settle the matter I seek to address herein-i.e. the

${ }^{27}$ Once more, my statements about the thesis sometimes refer generically to "adjudication" or "judicial reasoning" without explicitly distinguishing different types of judicial decision. This is merely for ease of reference. The variation specified in the body text that follows should be read into any statement or argument made here about the rights thesis.

${ }^{28}$ Dworkin, Law's Empire, supra note 1 at 244.

${ }^{29}$ Dworkin, Taking Rights Seriously, supra note 1 at 108-09, 111 n 1; Dworkin, Law's Empire, supra note 1 at 312, 338-39.

${ }^{30}$ Dworkin, Taking Rights Seriously, supra note 1 at $111, \mathrm{n} 1$.

${ }^{31}$ Ibid.

${ }^{32}$ Ibid. 
apparent conflict between the rights thesis and judicial resort to the FA-for the simple reason that the FA sometimes, or even mostly, features in common-law decisions. ${ }^{33}$

\section{IS JUDICIAL RESORT TO THE FA COMPATIBLE WITH THE RIGHTS THESIS?}

On the face of it, the FA appears to be a clear example of a policy argument, which, if the rights thesis is correct, has no place in civil adjudication. The FA does not focus on the conduct of the parties or the consequences of their conduct. It is not based on the merits of the claim itself in view of what the parties did or caused. What it says, instead, is that even if the lawsuit consists of a meritorious claim, it should be rejected in view of the risk of proliferation and excess of future lawsuits. The argument's central focus, then, is the potential volume of future cases and the demands it would place on judicial resources, which is a consideration exogenous to the merits of the claim itself and not specifically linked to the parties in question. To this extent, the FA also seems to be in tension with the requirement that like cases be treated alike. For it follows from the FA that two situations substantively similar in all respects, and thus giving rise to equally meritorious claims, may nonetheless be treated differently on the sole ground that in one situation the group of potential future claimants happens to be larger than in the other. ${ }^{34}$

However, as mentioned at the outset, Dworkin himself considers his rights thesis to be reconcilable with judicial resort to the FA. Their reconcilability becomes visible, according to Dworkin, when one brings to mind a distinction between abstract rights on the one hand and concrete rights on the other. ${ }^{35}$ An abstract right, Dworkin clarifies, "is a general political aim the statement of which does not indicate how that general aim is to be weighed or compromised in particular circumstances against other political aims". ${ }^{36} \mathrm{~A}$ concrete right, on the other hand, is a political aim "more precisely defined so as to express more definitely the weight [it has] against other political aims on particular occasions".37

\footnotetext{
${ }^{33}$ For the same reason, my primary focus in examining Dworkin's position will be its application to common-law cases.

${ }^{34}$ See largely consistent point made by Lord Roskill in Junior Books Ltd v Veitchi Co. Ltd, supra note 10 at 539.

${ }^{35}$ Dworkin, Taking Rights Seriously, supra note 1 at 98.

${ }^{36}$ Ibid at 93 .

${ }^{37}$ Ibid.
} 
Dworkin acknowledges that this distinction represents what is merely a difference in degree, but he does not seem to think this undermines its serviceability. He furnishes examples of rights that, he believes, lend themselves to classification in terms of that distinction. Thus, for example, the statement that "citizens have a right to free speech",38 refers to an abstract right, whereas the statement that "a newspaper has a right to publish defense plans classified as secret provided this publication will not create an immediate physical danger to troops" 39 refers to a concrete right. According to Dworkin, when judges in a civil dispute translate the rights of the parties from abstract rights into concrete ones, they should (and do) take into account the rights of potentially affected people who are not party to the dispute. Thus:

[i]f a judge appeals to public safety or the scarcity of some vital resource, for example, as a ground for limiting some abstract right, then his appeal might be understood as an appeal to the competing rights of those whose security will be sacrificed, or whose just share of that resource will be threatened if the abstract right is made concrete. ${ }^{40}$

Dworkin's comment is framed in somewhat inconclusive terms: "might be understood". I am not sure, however, what the word "might" means here exactly, and, since the above characterization of the decision seems essential to Dworkin's defence of the rights thesis, I take him to endorse this characterization. Now, judicial resort to the FA is, according to Dworkin, an example of this form of balancing between competing rights:

We find a different sort of example in the familiar argument that certain sorts of law suits should not be allowed because to do so would 'swamp' the courts with litigation. The court supposes that if it were to allow that type of suit it would lack the time to consider promptly enough other law suits

\footnotetext{
${ }^{38}$ Ibid.

${ }^{39}$ Ibid.

${ }^{40}$ Ibid at 100. He adds: "His argument is an argument of principle if it respects the distributional requirements of such arguments, and if it observes the restriction mentioned in the last section: that the weight of a competing principle may be less than the weight of the appropriate parallel policy." I am not sure, however, how material this last restriction actually is, given that, according to Dworkin, the example involves a competition between two principles, rather than a principle competing with policy. The additional weight given to a principle on one side of the scale qua principle would be offset by a similar addition of weight attached to the principle on the other side of the scale.
} 
aiming to vindicate rights that are, taken together, more important than the rights it therefore proposes to bar. ${ }^{41}$

I find Dworkin's attempt at reconciling the FA with his account to be unpersuasive. Dworkin's basic claim, his rights thesis, excludes policy from civil adjudication. Then, by way of clarification and qualification, the passages just quoted say: but judges in civil disputes may and sometimes do engage in a balancing exercise between, on the one hand, the disputants' rights and, on the other hand, the more remote rights of persons (members of a general class of unnamed individuals, e.g. potential users of a public resource) who are not parties to the dispute. This qualification, however, essentially introduces through the back door much of what the thesis initially appeared to exclude. For there are many public policy goals that can be expressed in terms of rights of individuals comprising the public: public safety can be described in terms of people's rights to life and security; healthcare policy can be couched in terms of individuals' right to a standard of living adequate for health and well-being; and a public aim of reducing unemployment rates can be expressed as a desire to protect people's right to work. The continuing expansion of human rights law over recent decades offers further indication of the potential compass of Dworkin's qualification and, thus, the extent of its discordance with his basic claim. ${ }^{42}$

I do not wish to deny that public policy goals such as the ones just mentioned are genuinely connected to rights. When Tom sues Bill for assaulting him, the legal right Tom is invoking has of course some relation to the policy goal of public safety, in that, for example, respect for this right is likely to contribute positively to public safety. But there is a crucial difference between this situation and a situation in which a court considers

\footnotetext{
${ }^{41}$ Ibid.

${ }^{42}$ The point made here shares some of the intuitions expressed in John Umana, "Note, Dworkin's 'Rights Thesis"' (1976) 74 Mich L Rev 1167 at 1179-81 (where it is observed that Dworkin is able to accommodate apparent counterexamples to his rights thesis "only by engaging in a conceptual 'gerrymandering' that abandons his original formulations of the principle-policy distinction"), and Greenawalt, supra note 21 at 1003 (where it is noted: "If we interpret Dworkin's theory to provide reasonable responses to questions of how courts are supposed to weigh interests of nonparties, the distinction between principles and policies becomes much more blurred and almost vanishes") and at 1016-26. However, Umana and Greenawalt seem at points sceptical as to the very viability of the principle/policy distinction, whereas my own view (as will be become clear in the sequel) is that the distinction (in its basic form, prior to Dworkin's adaptations) captures a normatively significant difference, even if Dworkin was wrong to regard it as a rigid boundary that categorically circumscribes permissible (and characteristic) judicial activity.
} 
possible future implications of its judgment for the safety of a general class of unnamed third parties - as, for example, when a court, in adjudicating a dispute between a police officer and his or her employer over the terms of employment, incidentally takes into account possible future implications of the judgment for the safety of potential users of police services. The best way of capturing this difference is to say that in the latter type of situation considerations of safety figure in the court's reasoning as a public policy concern. In denying just that, Dworkin offers what is not only a far less intuitive characterization of the situation, but also one that blurs a normatively important distinction between two different functions of the court: that of adjudicating a specific dispute between particular parties in accordance with the law, and that of helping to steer the law in desirable directions in terms of its wider implications for a larger class of people, members of society at large. ${ }^{43}$ As will become clearer in the following section, I do not deny that these two functions are sometimes simultaneously entangled in a single judicial decision. But this does not make them one and same, nor does it speak in favour of adopting a conceptual construction that only makes it harder to tell the difference between them. On the contrary, it reinforces the reasons for an analytical framework that tends to facilitate awareness of, and sensitivity to, the distinction.

To conclude this section, Dworkin's characterization of judicial resort to the FA as a policy-free decision seems to me to be far less cogent than the alternative, that is, a plain acknowledgement that judicial resort to this argument is an exercise of reasoning involving policy. I remain, therefore, of the view that the FA and the rights thesis are in conflict. Now, if this observation is accepted, the next likely question is: How should the conflict be resolved? Or, more specifically, should we endorse the rights thesis, and thus conclude that judges should not resort to the FA? Or, should we instead approve of judicial resort to the FA, and thus reject the rights thesis? I will advocate an intermediate approach. I will argue that, while Dworkin's thesis contains an important insight, it is making a hyperbolic claim that requires considerable qualification. Applying these observations to the specific question of the FA, I will put forward an operative suggestion as to the proper conditions for, and constraints on, judicial resort to the FA.

\footnotetext{
${ }^{43}$ Or, at least, preventing it from going in undesirable directions in terms of those wider social implications. The foregoing, it may be added, is comparable to the way John Bell speaks of the "political" aspects of the judicial role as involving the function of "giving direction to society" (John Bell, Policy Arguments in Judicial Decisions (Clarendon Press, 1983) at 6-7).
} 


\section{THE RIGHTS THESIS: INSIGHT AND HYPERBOLE}

I will start with what I think is the insight in the rights thesis. One important fact that the thesis usefully highlights is that a judge characteristically does not approach the task of deciding a case by asking the question: would it be best for society if the claimant wins the case, or if the defendant wins? Rather, the judge characteristically embarks on the task by asking, firstly, what the law is on the matter at hand, ${ }^{44}$ and which of the adversaries is entitled to win the case in accordance with the law. Unlike Dworkin, I am inclined to think that questions of policy may nonetheless feature in the decision, but - and this is a fact which, I believe, Dworkin's account usefully casts light upon-they are not the starting point of judicial reasoning. The characteristic starting point of judicial reasoning consists, instead, in an effort to derive the current decision from norms founded (at least in part) on past legislative or judicial decisions, and an attempt to draw a coherent link between these decisions. $^{45}$

That judges approach their task in this way is no mere happenstance. It is a method of decision embedded in their understanding of the role of a judge and rooted in some of the basic values underpinning the function of law in social life. Thus, for example, adherence to the requirement that like cases be treated alike helps render adjudication more impartial, and introduces a measure of fairness between litigants. A commitment to coherence serves to reduce the degree of arbitrariness that judicial decisions would otherwise involve, and makes an essential part of law's commitment to reason. ${ }^{46}$ And the judicial effort to ground the present decision in past decisions minimizes, as far as possible, elements of retroactive imposition by law — which echoes one of the central desiderata of the rule of law. ${ }^{47}$ Living

\footnotetext{
${ }^{44}$ By "the law" I mean here, roughly, a body of standards comprised, inter alia, of statutory rules, doctrinal principles, and precedents. It is not my purpose here to determine whether the content of this body of standards is identifiable through Dworkin's interpretive test or through a legal positivist test.

${ }^{45} \mathrm{Cf}$ comments in Regan, supra note 21 at 139 pointing out somewhat similar patterns of judicial reasoning.

${ }^{46}$ For a recent account of legal reasoning with a focus on coherence, see Amalia Amaya, The Tapestry of Reason: An Inquiry into the Nature of Coherence and its Role in Legal Argument (Hart 2015).

${ }^{47}$ Cf George Christie's remark that the desire to limit discretion (in the manner he specifies and associates with the rule of law) "is certainly one of the major attractions of the resort to principle" (Christie, supra note 26 at 540). Cf also Witting's arguments that policy-based reasoning is comparatively "unstable" and more prone to result in inconsistent rulings, and that courts will often
} 
up to these cherished standards is not just a worthy aim, but is in fact a prerequisite for the legitimacy of a legal system and its entitlement to demand citizens' compliance with its courts' rulings.

Dworkin is also correct, in my judgment, to point out that even when past legislative and judicial decisions are ambiguous and varied enough to support more than one possible outcome, adjudicative discourse does not simply cut loose from its aspiration to a principled judgment on the parties' entitlements. ${ }^{48}$ Even then lawyers and judges do not simply discard the legal materials as irrelevant. They continue to consider and debate distinctions and analogies between the present case and preceding ones, and persist in their attempt to show a coherent and principled link between their decision and what has been decided in the past. To appreciate this fact, it suffices to consider the sheer proportion of discussion devoted to past cases in even the most path-breaking tort judgments, such as those in Donoghue $v$ Stevenson, ${ }^{49}$ Hedley Byrne $v$ Heller \& Partners,${ }^{50}$ McLoughlin $v$ O'Brian, ${ }^{51}$ MacPherson v Buick Motor Co., ${ }^{52}$ and Sindell v Abbott Laboratories. ${ }^{53}$ Many times judges follow that mode of reasoning without explicitly stating so. At other times, however, it receives explicit manifestation in the judgment. Thus, for example, in Hunter $v$ Canary Wharf [1997] AC 655, a leading English case in the area of private nuisance, Lord Hoffmann remarks:

[T] he development of the common law should be rational and coherent. It should not distort its principles and create anomalies merely as an expedient to fill a gap. ${ }^{54}$

And in Fairchild v Glenhaven Funeral Services Ltd [2003] 1 AC 32, a notable case in the context of causation in negligence, Lord Nicholls comments:

not have before them the comprehensive information requisite to be well-placed for policymaking (Witting, supra note 24 at 569-70, 577, 579-80).

${ }^{48}$ See also Bell, supra note 43 at 224, referring to "the essential continuity in judicial methods in hard and easy cases".

${ }^{49}$ [1932] AC 562.

${ }^{50}$ [1964] AC 465.

${ }^{51}$ [1983] 1 AC 410.

52 (1916) 217 NY 382.

${ }^{53}$ (1980) 607 P 2d 924.

${ }^{54}$ At 707. 
To be acceptable the law must be coherent. It must be principled. The basis on which one case, or one type of case, is distinguished from another should be transparent and capable of identification. When a decision departs from principles normally applied, the basis for doing so must be rational and justifiable if the decision is to avoid the reproach that hard cases make bad law. ${ }^{55}$

What, then, is the exaggeration in Dworkin's rights thesis? The exaggeration is his denial that anything of what judges characteristically do and should do in the relevant legal areas is properly described as policymaking. ${ }^{56}$ Although policy arguments should generally not be the starting point or primary component of judicial reasoning, to deny that they have an essential role to play in adjudication is a step too far. There are cases that inextricably involve wide social and economic implications that are just too significant to be disregarded by the court - and consideration of those wider implications for society is most readily understood as an exercise that introduces an element of policymaking into the decision. ${ }^{57}$ Dworkin, as noted in the preceding section, did not suggest that courts should never consider those wider implications of their decisions, but he did insist that their doing so can be understood as an exercise involving only arguments of principle and no policy. As argued in the previous section, however, his attempt to square those instances with his rights thesis extends his notion of "principle" to the point of obscuring even the element of

\footnotetext{
${ }^{55}$ At 68 . See also Edmund Davies LJ's comments in Spartan Steel, supra note 8 at 40, and Lord Scarman's comments in McLoughlin v O'Brian [1983] AC 410 at 430-31. A few examples drawn from Canadian case law include, e.g., Canadian National Railway Co. v Norsk Pacific Steamship Co. [1992] 1 SCR 1021 at 1153, where McLachlin J. endorses a "principled, yet flexible, approach to tort liability for pure economic loss", such that "it will permit coherent development of the law"; Clements $v$ Clements [2012] SCC 32, where, in delimiting the material-contribution-to-risk doctrine, the court warns against undermining "the fundamental principle ... [that a] defendant in an action in negligence ... is a wrongdoer only in respect of the damage which he actually causes to the plaintiff ..." (at para 16); and Saadati v Moorhead [2017] SCC 28, where the court rejects the limitation of recoverability for mental injury to cases of "recognizable psychiatric illness", noting that such a limitation is grounded in "no principled reason" (at para 36). See also the High Court of Australia's comments in Sullivan v Moody (2001) 207 CLR 562 at para 49.

${ }^{56}$ Greenawalt's remark that "any theory is probably mistaken if it totally excludes from judicial consideration broad classes of arguments that would obviously be of weight for conscientious legislators dealing with a social problem" (Greenawalt, supra note 21 at 993), though framed somewhat more broadly than my comments above, seems befitting in this connection. See also at $1010-15$.

${ }^{57}$ To a similar effect, see Bell, supra note 43 at 6, 224.
} 
truth in the thesis. It is better, instead, to acknowledge that such instances of judicial reasoning involve an element of policymaking.

Tort law, an area of law particularly pertinent to this inquiry, ${ }^{58}$ offers some of the clearest illustrations of the essential part of policymaking in adjudication. If tort law was reducible to a set of definite norms, framed in precise terms which lend themselves to clearcut application, much more (though still not all) of the policymaking involved in this area could be left to the legislature. But the competing values and interests underpinning, or bound up with, tort law are often finely balanced and fact-sensitive to a degree that necessitates the use of open-ended and abstract normative concepts - e.g. "foreseeability", "proximity", and "fair, just, and reasonable", 59 "non-natural use"60, or the like-which gradually come to have more concrete content through their interpretation and implementation in court judgments, but which also retain a measure of elasticity and indeterminacy in their application. ${ }^{61}$ A court's interpretation and implementation of such normative terms may, in turn, have significant impact on the shape of law with wideranging social and economic implications. Thus, when a court determines the limits of liability by reference to the duty tests in negligence, ${ }^{62}$ the elements of private nuisance, or the rule in Rylands $v$ Fletcher, its decision may have knock-on effects such as driving up insurance premiums and imposing precautionary burdens that may inhibit socially valuable or even essential activities and/or affect the price of related services or products. If, for example, a court is to hold a local housing authority liable for failing to prevent a resident's assault on another resident, future forms of overly defensive behaviour of housing authorities in the operation of estates may result; ${ }^{63}$ and if the court is to hold a non-negligent apartment block owner liable under the rule in Rylands $v$ Fletcher for damage caused to a gas supplier by escaping water kept on the premises for domestic use, landlords may have

\footnotetext{
${ }^{58}$ Given that many of the cases wherein the FA has been invoked are tort cases.

${ }^{59}$ Caparo Industries Plc v Dickman [1990] 2 AC 605 at 617-18. Cf the bipartite test initially used in Anns v Merton LBC [1978] AC 728, which found favour with Canadian courts (see, e.g., Cooper $\checkmark$ Hobart, supra note 10).

${ }^{60}$ Rylands $v$ Fletcher (1868) LR 3 HL 330 at 339.

${ }^{61}$ See also Bell, supra note 43 at 269 , referring to "open-ended standards" as one of the factors accentuating "the increased willingness of judges to overrule and develop the common law".

${ }^{62}$ Whether its decision is conceived of as demarcating the scope of the duty or, following Goldberg and Zipursky, as determining whether to grant an exemption from the duty-see John Goldberg and Benjamin Zipursky, "The Restatement (Third) and the Place of Duty in Negligence Law” (2001) 54 Vand L Rev 657.

${ }^{63}$ See Mitchell v Glasgow City Council [2009] 3 All ER 205.
} 
to scale up their insurance to cover risks beyond those normally associated with domestic or commercial plumbing; ${ }^{64}$ and so on. In such cases, judges must consider policy lest their decisions steer the law-and social and economic affairs dependent on it-in consequentially wrong directions. ${ }^{65}$

To be sure, adverse social and economic policy repercussions of a court decision are something that might be set right or mitigated by a later legislative action. And the knowledge that such corrective action can be taken should arguably make it easier for judges to focus their attention on legal principles and leave wider policy concerns to the legislature. I do not wish to dispute the validity or relevance of this last consideration. But it must be borne in mind that its force will be limited if and insofar as there are grounds to suspect that no legislative action would actually be taken or that the time lag of a statutory reaction would be considerable, whether in view of present legislative priorities, a backlog of parliamentary work, or other factors. ${ }^{66}$ With this in mind, it seems unwarranted to assign invariable force, let alone invariably conclusive force, to the potential of ameliorative statutory response.

The observations made in the previous paragraphs combine to support the following conclusion: although the primary task of civil judges is to render principled decisions on the parties' entitlements according to the law, policy arguments sometimes do and should feature in their decisions. Arguments of principle and arguments of policy both have essential roles to play in civil adjudication. The need to resort to policy arguments, in at least some judicial decisions, cannot be eliminated, but nor can the reasons that militate against judicial policymaking and call for adherence to principle. Civil law adjudication, and tort adjudication in particular, is an arena of ineliminable tension (or, at any rate, potential tension) between principle and policy. ${ }^{67}$

\footnotetext{
${ }^{64}$ See Transco plc v Stockport MBC [2004] 1 All ER 589.

${ }^{65}$ A similar point finds expression in Neil MacCormick's rhetorical question: "Is it not relevant to ask what will be the outcome if it be ruled that all who engage in activities which may cause nonphysical damage to other persons owe to those at risk a duty to take reasonable care, and an obligation of reparation if they cause such economic loss by failure to take reasonable care?" (DN MacCormick, "Dworkin as Pre-Benthamite" (1978) 87:4 Philos Rev 585 at 595).

${ }^{66}$ See Greenawalt, supra note 21 at 1004-05 (noting the legislature's lack of time or political interest to engage itself in establishing rights for every area of the common law).

${ }^{67}$ How does my position relate to legal realism? It is essential to distinguish in this regard between moderate and extreme views associated (correctly or not) with the label "legal realism". By
} 
I wish to consider a possible response to my argument. The response puts forward the following construction of Dworkin's position by way of defence against my criticism. According to Dworkin, legal interpretation involves an assessment on two dimensions: fit (the degree to which a given interpretation fits the practice) and justification (the degree to which that interpretation presents the practice in an appealing light from an evaluative perspective of political morality). ${ }^{68}$ When the assessments on these two dimensions pull in different directions - i.e. when a given interpretation has considerable justificatory appeal but a comparatively low level of fit, or vice versa - some form of trade-off between them may be required: ${ }^{69}$ the interpretation adopted should be such that it reflects an optimal balance between "fit" and "justification" ${ }^{70}$ With this in mind, the opponent might suggest that what I argued to be the "ineliminable tension between principle and policy" can actually be assimilated into Dworkin's conception of the interplay between "fit" and "justification". On this understanding, the aspect of "justification" in the interpretive exercise takes into account (inter alia) policy considerations for or against a given interpretation of the law, whereas the constraint of "fit" secures the type of consistency with past decisions that characterizes arguments of principle-it turns what would otherwise be an exercise of policymaking into a decision of principle.

"extreme" I mean a position denying that legal doctrine, rules, and principles make (and/or should make) any real difference to judicial decisions, and regarding them as no more than window dressing or a means of rationalization. This stance is clearly inconsistent with my position, but only few, if any, legal realists have actually endorsed it in this unqualified form. By "moderate", on the other hand, I mean a range of positions denying that legal doctrine, rules, and principles determine alone judicial decisions, but acknowledging that they contribute to those decisions along with other factors, such as the judge's political orientation, ideological outlook, and social background. Described at this level of generality, moderate legal realism is not inconsistent with my view, though there may well be some other, more specific points of disagreement, such as over the degree of influence legal doctrine, rules, and principles should and do exert on the decision. For a pertinent discussion of different varieties of legal realism, see Roger Cotterrell, The Politics of Jurisprudence: A Critical Introduction to Legal Philosophy, 2nd ed (Oxford University Press, 2003) Ch 7. See also Brian Leiter, Naturalizing Jurisprudence: Essays on American Legal Realism and Naturalism in Legal Philosophy (Oxford University Press, 2007) esp Ch 1; Hanoch Dagan, "Doctrinal Categories, Legal Realism and the Rule of Law" (2015) 163 U Pa L Rev 1889.

${ }^{68}$ See, e.g., Dworkin, Law's Empire, supra note 1 at 228-39.

${ }^{69}$ See, e.g., ibid at 246-47 (noting that even after the level of "fit" requisite for an interpretation to be eligible has been satisfied, "questions of fit surface again, because an interpretation is pro tanto more satisfactory if it shows less damage to integrity than its rival").

${ }^{70}$ It should be noted that the trade-off Dworkin envisages does not consist in a freestyle balancing between "fit" and "justification", but a structured reasoning process governed by conditions and constraints (such as the threshold level of "fit" requisite for an interpretation to be eligible) that shape the interaction between "fit" and "justification". 
The above response is, I suggest, misguided on a number of counts. Perhaps most pertinently for the present analysis, the response misconceives Dworkin's position on the type of justifications that may appropriately figure in interpretation of common law. Dworkin does not accept that the justifications figuring in this type of interpretation may take into account considerations of policy. ${ }^{71}$ As was noted earlier, he distinguishes in this respect the interpretation of statute and the interpretation of common law. Regarding the latter, he unequivocally bars recourse to policy justifications. ${ }^{72}$ Thus, for example, Dworkin states that when Hercules, his hypothetical ideal judge, interprets judicial enactments, as opposed to statute, "he will fix to the relevant language only arguments of principle, because the rights thesis argues that only such arguments acquit the responsibility of the 'enacting' court.,"73

Now suppose the opponent concedes the point just made and offers again his or her initial response with the only difference that it is no longer presented as Dworkin's position. In this variant, the opponent accepts that, by allowing policy justifications to figure in common-law interpretation, he or she has departed from Dworkin's position. But (as in the original response) the opponent insists that adherence to the "fit" requirement imbues the decision (including any element of policy it would otherwise contain) with a quality of principle. This variant response is no longer accountable as a description of Dworkin's position, but it is guilty of another mistake. It expects the "fit" requirement to perform a job beyond its ability. Observance of the "fit" requirement cannot wipe out elements of policy that had been taken into account by the decision-maker, nor can it transform them into something that is purely and only an argument of principle. By this I do not mean to suggest that the "fit" requirement does not impose a genuine constraint on the decision-maker.

\footnotetext{
${ }^{71}$ The objection is also wrong to impute to Dworkin the thought that an otherwise unprincipled interpretation becomes principled merely by satisfying the requirement of fit with past decisions. In fact, according to Dworkin, there are other, independent conditions of content that an interpretation must meet in order to qualify as a principled interpretation in the requisite sense. Crucially, its content must be such that it states (or, at least, figures in or follows from) a principle of justice, fairness, or procedural due process (Dworkin, Law's Empire, supra note 1 at 225). See, for example, at 240-44, Dworkin's illustration of how Hercules would go about the facts of McLoughlin $v$ O'Brian, where Dworkin discards some candidate interpretations of the law as ineligible on the above ground.

${ }^{72}$ Dworkin, Law's Empire, supra note 1 at 244 (stating that “[j] udges must make their commonlaw decisions on grounds of principle, not policy").

${ }^{73}$ Dworkin, Taking Rights Seriously, supra note 1 at $111 \mathrm{n} 1$. See also Dworkin, Law's Empire, supra note 1 at 338-39, where he contrasts common-law precedents with statute.
} 
However, in many instances the available body of past precedents exhibits a degree of heterogeneity, incompleteness, or uncertainty that leaves the judge faced with more than one alternative resolution defensible in terms of the "fit" requirement. In such cases, even if the "fit" requirement contributes to the decision, it is illusory to suppose that its contribution somehow eliminate from the judgment policy factors that the judge had taken into consideration. ${ }^{74}$

\section{WHAT IMPLICATIONS FOLLOW FOR THE FA?}

Above I have argued for an understanding of civil law adjudication as an arena of ineradicable (potential) tension between principle and policy. As part of this argument, I have highlighted some general (though defeasible) reasons against judicial policymaking. I now wish to utilize these observations as a framework of analysis in addressing the particular problem of the FA. The first thing to note as I approach this task is that, although the reasons against judicial policymaking are general in scope, their force is sensitive to factors that change with the context and the type of policy argument involved. I will draw attention to one such factor which has particular relevance to an analysis of the FA: namely, the question of how tight or loose the connection is between the policy argument considered by the court and the substance of the lawsuit at hand; ${ }^{75}$ or, in other words, how remote the argument is from material facts that bear on the merits of the claim. The more remote it is, the wider the departure of the court from what has been identified here as its paradigmatic task - that is, providing a principled resolution to the dispute between the parties - and, thus, the harder it becomes to justify and defend the court's resort to that policy argument.

Consider an example of a policy argument that exhibits a fairly close connection to the substance of the lawsuit in question. The English case $J D(F C) v$ East Berkshire

\footnotetext{
${ }^{74}$ The point in the body text bears some resemblance to MacCormick's point that in hard cases often both disputants can appeal to settled and sound principles - and associated rights - and the decision which of these rights to uphold turns on "a characteristically legal mode of consequentialist argument" involving, inter alia, reference to concepts such as "public policy" (MacCormick, supra note 65 at 594-95, 597-98).

${ }^{75}$ There are other parameters by which policy arguments could be classified. See, for example, Bernard Rudden's classification of arguments from consequences (a theme intimately connected to policy), distinguishing between what he calls "behavioural consequences", "judicial consequences", and "inbuilt consequences" (Bernard Rudden, "Consequences" (1979) 24 Jurid Rev 193).
} 
Community Health NHS Trust ${ }^{76}$ involved parents who brought actions for negligence against healthcare and local authorities, claiming damages for alleged psychiatric harm caused to them as a result of false allegations that they had abused their children. The House of Lords dismissed the parents' appeal on the basis that no duty of care was owed to them by the defendants. The main reason was the following policy consideration. When dealing with suspected child abuse, the relevant authorities should act in the best interest of the child, and while the child's interest is normally congruent with the parents', that is not so where the possibility of parental abuse arises. To recognize a duty of care towards the parent may thus unduly inhibit the authorities in fulfilling their main function and may compromise the protection of children against abuse. Hence, while a duty of care is owed to the children, it is not owed to their parents. This consideration is best characterized as a policy consideration, because it is focused on the collective goal of protecting children from abuse (a goal which does not serve in any direct way the children of the appellants, as the accusations against the appellants proved to be unfounded). At the same time, however, it is directly and inherently connected to substantive characteristics of the lawsuit at hand: namely, the facts that the case involved suspected child abuse, that the defendants were public authorities in charge of dealing with such suspicions, and that the claim was for negligence towards the parents rather than their children. These factors go to the heart of the claim. When a policy consideration is so closely intertwined with substantive and material facts of the claim, it is hard to see how a court could or should sever it from the rest of the claim and disregard it.

Now contrast the above-described policy consideration with the FA. The FA bears a much looser connection, if any, to the substance of the lawsuit in question, and a connection that is far more contingent. The FA, to reiterate, is an argument that calls for the rejection of a legal claim due to the fear of a large volume of future claims placing excessive demands on the court system. This description of the argument includes no reference to the particular facts of a case, and it is a natural description, not one artificially cast at a high level of abstraction to avoid reference to concrete facts. Indeed, the potential of a large number of future claimants can exist in different cases that share nothing in substance. And, vice versa, the potential number of future claimants can widely diverge between two substantively similar cases, with the only difference that, say, one involves a popular and socially

${ }^{76}[2005]$ UKHL 23. 
widespread activity while the other involves an activity undertaken only by few. ${ }^{77}$ The FA's distinctive lack of connection to the substance and merits of the claim makes the resort to it, ceteris paribus, harder to defend against an attack on grounds discussed earlier, such as the value of substantive fairness and coherence in law.

The following objection might be raised at this point. My claim that the FA is distinctively extraneous to the substance and merits of the lawsuit is mistaken, it might be argued, because when a judge considers the FA he or she is likely to take into account, among other factors, the gravity of the interests or rights involved in the relevant legal action. Thus, for example, when the substantive interests or rights at stake are of relatively little weight, all else equal, the judge is likely to be more receptive to the FA, and vice versa. Now, the first point I should make in reply is that I am quite uncertain about the extent to which the facts stated in the objection are correct - that is, the extent to which judicial response to the FA actually depends on the importance of the interests or rights involved in the claim. One body of decisions that may give rise to such doubts is the English case law on negligence liability for psychiatric injury: the rather stringent limitations on the scope of liability that largely endure in this area of law result, at least in part, from floodgates concerns. Yet, few would deny (at least presently and in recent times $^{78}$ ) that the claimant's protected interest, his or her mental integrity, carries great importance, and few would suggest that the type of harm involved, psychiatric illness, is of little significance - as reflected, e.g., in Lord Steyn remarks in White v Chief Constable of South Yorkshire Police ${ }^{79}$ that "psychiatric harm may be more serious" 80 and "may be far more debilitating than physical harm". ${ }^{81}$ Now, the example of psychiatric harm does not go as far as disproving the objection's factual veracity, because the extent to which the FA has contributed to judicial decisions in this area is itself unclear, and because the proviso used

\footnotetext{
${ }^{77}$ See related comment by v Lord Roskill in Junior Books Ltd v Veitchi Co. Ltd, supra note 10 at 539.

${ }^{78}$ This has not always been the case- - see, e.g., Harvey Teff, Causing Psychiatric and Emotional Harm: Reshaping the Boundaries of Legal Liability (Hart, 2009) at 40, noting that the early common law's approach was "virtually programmed to entrench primitive suspicions and prejudices about 'invisible', intangible harm".

${ }^{79}$ Supra note 8.

${ }^{80}$ Ibid at 32.

${ }^{81}$ Ibid at 31. See further comment in this general vein in Robert Stevens, Torts and Rights (Oxford University Press, 2007) at 55; Arthur Ripstein, Private Wrongs (Harvard University Press, 2016) at 87 and 252-53.
} 
in the objection, "all else equal", may not have applied in those cases. But the example does, at the very least, place a question mark over the facts stated in the objection.

But let us now suppose arguendo that the facts stated in the objection are correct. Even so, the objection should be rejected on other grounds. There is a crucial difference between the way material facts of a case figure in ordinary judicial reasoning and the way they might figure in judicial consideration of the FA. In ordinary judicial reasoning (in the context of civil disputes) the primary question is whether the claimant has a valid cause of action, and, correspondingly, whether the defendant is liable. If the answer is positive, the claimant is deemed to have a legal entitlement (to a remedy whose exact type and size remain to be determined). The meritorious nature of the claim is not a question of degree or relative importance: the claimant is not required to establish, for example, that his or her cause of action is very important or more important than some other causes of action which other claimants might have, but only that he or she has $a$ cause of action. When it comes to judicial consideration of the FA, on the other hand, matters are very different: here, according to the objection, the court takes into account the relative importance of the rights at stake. This assessment of relative importance forms an unusual hurdle for the claimant, over and above the ordinary need to establish that his or her claim is meritorious. Why is the claimant required to overcome this unusual extra hurdle? Because of the fear of a potential flood of litigation - a reason that has nothing to do with the merits of his or her claim. This means that the claimant in such cases is subject to treatment different from claimants in other cases (where there is no floodgates concern), and the ground for this different treatment is entirely extraneous to the merits of his or her claim. We can see now that, even when the facts stated in the objection are assumed to be correct, there remains a crucial, and problematic, sense in which judicial resort to the FA rests upon extraneous grounds. The objection, therefore, fails to address the normative concerns highlighted here against judicial resort to the FA.

Another consideration is worth noting at this point. Invokers of the FA often seem to implicitly regard the available amount of judicial recourses as static. But is that assumption always necessarily correct? An increase in the volume of lawsuits may prompt a government to respond by channelling more public funds to the judiciary so as to augment existing judicial personnel. To ignore this possibility is, in effect, to put the cart before the horse: namely, to shape the law according to the existing amount of judicial resources, 
instead of allowing that amount to be changed in response to the law. ${ }^{82}$ The intuitively correct order is the latter. Of course, one should not be naïve enough to assume that additional judicial resources would always be made available in response to growing need; and when one has strong enough reason to believe otherwise, it may appropriately inform the background factual assumptions relevant to an assessment of the FA- as will be seen in the solution I will shortly propose. But the basic point remains that, in what generally and intuitively seems to be the sounder direction of reasoning, the amount of judicial personnel should be determined by substantive needs generated by the law, not the other way around.

What, then, is the upshot for the FA? The analysis in this section, if correct, shows that there exist strong normative considerations against judicial resort to the FA. These derive primarily from the general considerations against judicial policymaking, but they carry particular force in the specific context of the FA, whose exogenous nature stands in an especially sharp contrast to values associated with principled adjudication. Does it follow that courts should never accept the FA? No. The considerations highlighted here against the FA are strong, but their strength is a quantitative attribute that remains relative. It does not turn them into absolute considerations, which would entail an approach as sweeping as the proverb: "Let justice be done even though the heavens fall". And it is conceivable that the pragmatic concern about a looming flood of litigation might, on occasion, be so compelling and well grounded that it counterbalances and even overrides the normative considerations discussed above. It would be irresponsible for the court system to entirely divest itself of the possibility to resort to the FA on those occasions, rare and exceptional though they may be.

These comments gesture to a solution that can conveniently be characterized as a presumption against judicial resort to the FA: a decisional tool that inclines the decisionmaker against acceptance of the FA, but, as is normally the case with presumptions, remains susceptible to override when the case for using the FA is particularly strong. ${ }^{83}$ In

\footnotetext{
${ }^{82}$ In a somewhat similar vein, see FKH Maher and RC Evans, "Hard Cases, Floodgates, and the New Rhetoric" (1985) 8 U Tas L Rev 96 at 107 (where it is noted that part of the answer to floodgates concerns is "an increase in court personnel and a proliferation of other adjudicative bodies" that have taken place in the twentieth century); and 125 (where is it noted that "if there is ... a large number of grievances which the law should redress, then it is not for the judges to refuse justice on those grounds, but for the legislature to provide a more efficient administration").

${ }^{83}$ A similar solution has been advocated by Marin Levy regarding what she calls "court-centred floodgates arguments" in a methodical work on the floodgates argument in US adjudication (Marin
} 
determining whether this presumption should be overridden in a given case, I suggest that specific consideration should be given to the following questions and factors. (1) Overwhelming magnitude: is the volume of additional lawsuits expected to ensue if the court finds for the claimant of overwhelming magnitude (relative to the resources available to the judicial system)? The suggested presumption against the FA should not normally be overridden when the answer is negative. (2) Evidential support: the fear that such volume of lawsuits would ensue should be based not on mere surmise or speculations, but on concrete evidence - for example, factual data indicating the potential number of future claimants, the likely frequency of claims, and the existing volume of claims dealt with by the system. (3) The absence of alternative caseload management solutions: it should be established that alternative caseload management solutions_-including, for example, feasible and moderate adjustments to the resources allocated to the judicial system and/or probable recourse to efficient modes of litigation such as class action-are not likely to be effective. The foregoing list is not meant to exhaustively capture all relevant factors, but merely to highlight some particularly relevant ones.

A couple of additional comments should be made before this article is brought to a close. First, it is worth reemphasizing the distinction drawn at the outset between the version of the floodgates argument discussed here (the FA) and other arguments that sometimes appear under, or in connection with, the label "the floodgates argument". ${ }^{84} \mathrm{~A}$ discussion of those other arguments must await another opportunity, but it can nonetheless be noted here that at least some of those arguments appear, prima facie, to differ significantly from the FA in terms of their normative status. Take, for example, the concern not to impose on the defendant a disproportionately large or indeterminate amount of liability, and the related concern to avoid an undue inhibition of a socially beneficial activity pursued by the defendant. Reliance on such considerations may be easier to justify than reliance on the FA, because the former are closer in focus to the substance of the claim and its material facts. Indeed, they seem to be inextricably linked with factors such as the

K Levy, "Judging the Flood of Litigation" (2013) 80 U Chi L Rev 1007, esp at 1072). Levy comes to this conclusion on doctrinal grounds through an analysis of American case law, whereas here it is founded on theoretical grounds and is not jurisdiction-specific. See also the discussion in Toby $\mathbf{J}$ Stern, "Federal Judges and Fearing the "Floodgates of Litigation"” (2003) 6 U Pa J Const L 377 (where Stern concludes that "arguments that a court is bound to rule lest the floodgates of litigation be opened should be discounted and mostly, if not entirely, abandoned" [p 422]).

${ }^{84}$ See text accompanying notes 8-13 above. 
type and degree of risk generated by the defendant's activity, whether and how well the defendant is placed to take effective precautions, and whether and how the imposition of liability would affect any valuable function fulfilled by the defendant. Such considerations appear, therefore, to be considerably less susceptible to the objection levelled against the FA due to its exogenous nature.

Second, it is worth distinguishing the objection discussed here against the FA from another type of critical response to it. Critics of the FA have, inter alia, called into question its factual premises, suggesting that the fear of multitudinous claims flooding the court system is often a factually unwarranted or an exaggerated fear. Thus, for example, Deakin, Johnston, and Markesinis have pointed out, among their several different reservations about the floodgates argument, that it

can be accorded more significance than it deserves, since experience has shown that even where liability has been recognised (thus creating new dutysituations) the corresponding increase in litigation has not, on the whole, been as great as feared. ${ }^{85}$

While this type of argument expresses scepticism about the factual component of the FA, the arguments focused on in this article, and thus the main grounds for the suggested presumption, are normative. They are arguments from the role and value of principled adjudication. Having said that, the two types of argument - the factual and the normativedo not exclude one another and may jointly support the suggested presumption.

A final clarification should be made about the relationship between my argument and past judicial treatment of the FA. There are several court judgments wherein different expressions of scepticism have been made regarding the FA and its force as a ground for a

\footnotetext{
${ }^{85}$ Simon Deakin, Angus Johnston, and Basil Markesinis, Tort Law, 7th ed (Oxford University Press, 2013) at 30. For other arguments made there regarding the floodgates argument, see at 10-11, 30, 142. To a similar effect, see McLoughlin v O'Brian, supra note 55 at 420 (Lord Wilberforce), 442 (Lord Bridge), and 425 (Lord Edmund-Davies); Maher and Evans, supra note 82 at 107. See also Rachael Mulheron, "Rewriting the Requirement for a 'Recognized Psychiatric Injury' in Negligence Claims" (2012) 32 Oxford J Leg Stud 77 at 107-11 (where, in arguing against the recognized-psychiatric-illness requirement for mental injury redress, Mulheron highlights legal tools by which the number of potential claims could effectively be 'ring-fenced' if her proposal is adopted).
} 
decision. ${ }^{86}$ The conclusions arrived at here are not at odds with the general tenor of these judicial remarks. Instead of calling for a radically different approach, this article's main contribution to existing discourse on the FA, as I see it, lies elsewhere and can be summed up as follows. (1) One of the distinctive attributes of my discussion of the FA is that it rests upon a jurisprudential analysis. It thus offers a theoretically underpinned argument that, if accepted as sound, may serve to test, reinforce, change, or refine (as the case may be) one's otherwise held view regarding the FA. (2) It is hoped that the present analysis may help create a clearer framework of deliberation about the FA and other versions of the floodgates argument. Despite what was said above about past judicial treatment of the FA, the legal position remains somewhat unclear. Part of the uncertainty results from the existence of multiple versions of the floodgates argument, as noted at the outset of this article; and the fact that different versions-which, if my analysis is correct, seem to merit different treatment - may be intertwined in one decision with insufficiently clear and explicit differentiation between them. With this in mind, part of my purpose has been to promote a more discriminative discussion by singling out for a separate analysis one particularly problematic version of the floodgates argument. (3) Scepticism towards the FA can take different forms. Here I have advocated one, which implies a rejection of some others. Take, for example, the stance adopted by certain judges who have cast their disfavour of the FA in absolute terms, such as Holt CJ's categorical statement in Ashby $v$ White ${ }^{87}$ that "it is no objection to say that it will occasion a multiplicity of actions". ${ }^{88}$ The approach advocated here is different in that, instead of categorically barring the FA, it adopts an overridable presumption against it. It leaves open the possibility of judicial resort to the FA but reserves

\footnotetext{
${ }^{86}$ For example, Junior Books Ltd $v$ Veitchi Co. Ltd, supra note 10 at 539; $R$ (on the application of Prudential plc and another) $v$ Special Commissioner of Income Tax and another [2013] UKSC 1 at paras 127-28. See also Rothwell v Chemical \& Insulating Co. Ltd, supra note 8 at paras 17, 50, 79.

${ }^{87}$ (1704) 2 Ld. Raym. 938.

${ }^{88}$ Ibid at 955 . He continues: "for if men will multiply injuries, actions must be multiplied too, for every man that is injured ought to have his recompense". Compare the following remarks: "I am not impressed by that fear [i.e. a fear of floodgates opening] — certainly not sufficiently to deprive this plaintiff of just compensation for the reasonably foreseeable damage done to her" (Lord Russell in McLoughlin v O'Brian, supra note 55 at 429); "It would surely be wrong to exclude from probation a claim which is so strongly based, merely because of anxiety about the possible effect of the decision upon other cases where the proximity may be less strong" (Lord Fraser in Junior Books Ltd $v$ Veitchi Co. Ltd, supra note 10 at 533); "I see no reason why, if it be just that the law should henceforth accord that remedy, that remedy should be denied simply because it will, in consequence of this particular development, become available to many rather than to few" (Lord Roskill, Junior Books Ltd v Veitchi Co. Ltd, supra note 10 at 539).
} 
it to occasions where the case for doing so is especially compelling in terms of the scale of the anticipated caseload, the level of certitude with which it is foreseen, the absence of alternative solutions for the expected problem of case backlog, and other relevant factors.

\section{CONCLUSION}

The analysis in this article has juxtaposed a jurisprudential thesis and a practical problem in an attempt to gain critical insight into both. The jurisprudential thesis is Dworkin's claim that civil courts are and should be a forum of principled decisions, not policymaking (a claim also known as "the rights thesis"). The practical problem concerns the so-called "floodgates argument", or, more specifically, a version of this argument discussed by Dworkin (and dubbed here the FA) which focuses on the court system's capacity to adjudicate the volume of lawsuits anticipated if a given lawsuit is accepted. The observations made here can be divided into three categories: the first concerns the relationship between the rights thesis and the FA (Section II); the second concerns the veracity or falsity of the rights thesis (Section III); and the third concerns the proper role, if any, of the FA in judicial reasoning (Section IV).

In Section II, I argued that judicial resort to the FA is incompatible with the rights thesis. I considered Dworkin's attempt to reconcile the two, and found it to be unconvincing. According to Dworkin, when the court appeals to the scarcity of some vital resource, this might be understood as an appeal to principles protecting the rights of members of the public (not party to the dispute) to their just share of that resource. Judicial resort to the FA, Dworkin seems to suggest, can be understood along these lines. Here the relevant resource is judicial time, and the third parties whose rights are at stake are individuals whose future access to judicial remedy would be compromised if the court would open the floodgates. This line of argument, I have claimed, suffers from three interconnected weaknesses: (1) given that many public policy goals can be expressed in terms of rights of individuals comprising the public, the argument essentially introduces through the back door much of what the rights thesis initially seemed to exclude-it thus drastically waters down the rights thesis; (2) it blurs a normatively important distinction between the court's function as a forum of adjudicating disputes and the court's part in developing the law in socially and economically desirable directions in the light of its wider future implications for the public at large; and (3) its characterization of the latter function 
of the court - and, as part of it, of judicial resort to the FA - as a policy-free exercise is contrived and counter-intuitive.

In Section III, a critical assessment of the rights thesis has led to a mixed conclusion. I have found it to be mistaken in one way, but instructive in another. Its mistake, I have argued, lies in denying that anything of what civil judges characteristically do and should do is properly described as policymaking. In fact, there are cases that require judicial consideration of wide social and economic implications that Dworkin himself did not necessarily wish to exclude from the court's deliberation, but which, contrary to his view, introduce an element of policymaking into the decision. The rights thesis is instructive, however, in that it puts in sharp focus that which is the primary task of courtsit makes it clear, in other words, that the court's primary task is not to render a decision that would best serve society, but to render a principled decision on the parties' entitlements according to the law. When a judge engages in policymaking, then, he or she is doing something that, even if warranted on balance, departs from and stands in tension with a central aspect of the judge's role. While the need to engage in policymaking in at least some cases cannot be eliminated from adjudication, nor can the reasons articulated by Dworkin against judicial policymaking, which continuously call for adherence to principle.

In Section IV, the FA's normative standing has been examined in the light of the foregoing conclusions. The reasons previously identified against judicial policymaking, I have argued, carry particular force against judicial resort to the FA. Their greater force in this context, I have observed, is a result of the FA's marked lack of connection to the substance and merits of the relevant claim. The FA's markedly extraneous nature means that resorting to it involves a particularly sharp break and wide departure from the court's primary task of providing a principled resolution to the legal dispute between the parties before it. And this, in turn, makes the resort to the FA, ceteris paribus, harder to defend. Harder, but not always impossible: since the strength of the reasons against resort to the FA remains relative rather than absolute, they are open to override in circumstances which give rise to an especially compelling floodgates concern.

On these grounds, I have proposed that a presumption against judicial resort to the FA should be adopted: a decisional tool that generally inclines the decision-maker against acceptance of the FA, but which can nonetheless be overridden when the case for using the 
FA is particularly strong. I have further proposed a number of relevant criteria as to whether the presumption should be overridden in a given case. The presumption should not normally be overridden, I have argued, unless: (1) the volume of additional claims excepted is of overwhelming magnitude; ${ }^{89}$ (2) the fear that such volume of claims would ensue is based on concrete evidence; and (3) it is established that alternative measures of caseload management-including, for example, feasible and moderate adjustments to the resources allocated to the judicial system and/or likely recourse to efficient modes of litigation such as class action — are inapplicable or not likely to be effective.

${ }^{89}$ That is, overwhelming magnitude relative to the resources available to the judicial system. 